\section{Evidence-based process for decision-making in the analysis of legal demands for medicines in Brazil}

\author{
Processo de tomada de decisão baseado em \\ evidências na análise das demandas judiciais \\ de medicamentos no Brasil
}

\author{
Proceso de toma de decisiones, basado en \\ evidencias científicas, desde el análisis de \\ demandas judiciales de medicamentos \\ en Brasil
}

Tatiana Aragão Figueiredo 1 Claudia Garcia Serpa Osorio-de-Castro 2 Vera Lúcia Edais Pepe 2

\author{
${ }^{1}$ Instituto de Tecnologia \\ em Fármacos, Fundação \\ Oswaldo Cruz, Rio de Janeiro, \\ Brasil. \\ ${ }^{2}$ Escola Nacional de Saúde \\ Pública Sergio Arouca, \\ Fundação Oswaldo Cruz, \\ Rio de Janeiro, Brasil. \\ Correspondence \\ T. A. Figueiredo \\ Complexo Tecnológico de \\ Medicamentos, Instituto de \\ Tecnologia em Fármacos, \\ Fundação Oswaldo Cruz. \\ $A \nu$. Comandante Guaranys \\ 447, Rio de Janeiro, $R J$ \\ 22775-903, Brasil. \\ tatianafigueiredo@far.fiocruz.br
}

\begin{abstract}
Legal actions have been playing a significant role as an alternative pathway to access to medicines in Brazil. These lawsuits demand medicines used in Primary Health Care as well as medicines that are still in clinical research and have not been market approved by the Brazilian National Agency for Sanitary Surveillance (ANVISA). The goal was to analyze medicines demanded through lawsuits brought to the judicial district which includes the city of Rio de Janeiro, Brazil, from July/2007 to June/2008. The medicines in 281 lawsuits were examined for their respective indications, classified according to their presence in publicly-funded lists, market approval by ANVISA, compliance with national clinical guidelines, existence of alternative therapies in lists and support of indication by scientific evidence. Six different categories were described, which are deemed useful to managers and the Judiciary in decision-making. The support of evidence is of utmost importance for medicines that are not included in public funding lists and also for those with no available therapeutic alternatives.
\end{abstract}

Evidence Based Medicine; Pharmaceutical Services; Right to Health; Health Technology Evaluation

\section{Resumo}

Demandas judiciais têm desempenhado um papel importante como forma alternativa de acesso a medicamentos no Brasil. Tais ações judiciais pleiteiam desde medicamentos usados na atenção básica até aqueles ainda em pesquisa clínica e sem registro no país pelo órgão sanitário local (Agência Nacional de Vigilância Sanitária ANVISA). O objetivo foi analisar os medicamentos presentes nas demandas judiciais da Comarca da Capital do Rio de Janeiro, Brasil, no período de julho/2007 a junho/2008. Os medicamentos presentes em 281 ações judiciais foram examinados em relação à sua indicação terapêutica, e classificados de acordo com a presença em listas de financiamento público, a aprovação pela ANVISA, o cumprimento da indicação de diretrizes clínicas nacionais, a existência de terapias alternativas em listas de financiamento público e a existência de evidências científicas. Foram descritas, seis categorias diferentes, consideradas úteis para os gestores da saúde e do Judiciário no processo decisório. A busca de evidência científica é importante para os medicamentos que não estão incluídos nas listas e também para aqueles sem alternativas terapêuticas.

Medicina Baseada em Evidências; Assistência Farmacêutica; Direito à Saúde; Avaliação de Tecnologias de Saúde 


\section{Introduction}

Brazil's 1988 Constitution is a legal landmark that defines healthcare as a universal right which must be guaranteed by the Government. The Brazilian Unified National Health System (SUS) is founded on various principles, the most significant being universal access to healthcare and comprehensiveness. SUS has the responsibility of guaranteeing comprehensive therapeutic services, including pharmaceutical services 1 .

Approval by the Brazilian National Agency for Sanitary Surveillance (ANVISA) allows the pharmaceutical product to enter the market in the country; nevertheless market approval does not signify availability or funding by SUS. The incorporation of medications into SUS is carried out by a complex evidence-based process of medicine selection, involving health authorities at federal, state and municipal government levels which results in medicine lists belonging to three different funding components of pharmaceutical services. The first one is the so-called basic component, which refers to medicines used in primary health care. The second component refers to strategic medicines which includes those used to treat endemic conditions, such as infectious diseases (e.g. HIV/AIDS, tuberculosis, Hansen's disease, leishmaniasis, malaria) and specific programs (e.g. smoking, lupus erythematosus and multiple myeloma) ${ }^{2}$. The third component deals with specialized medicines, those used in the high-cost treatment of rare conditions and also for second or third-line treatment options of highly prevalent diseases ${ }^{3}$. For this third component there is an access strategy at the outpatient level, with diagnostic and therapeutic criteria established by Clinical Protocols and Therapeutic Guidelines developed and updated by the Brazilian Ministry of Health (PCDT).

In spite of the progress in pharmaceutical services that has been made over the last decade, there are still unresolved issues surrounding citizens' access to medicines. Increasingly aware of their rights, citizens have been taking a more active role in seeking access, often resorting to individual litigation $4,5,6,7$. In the last few years there has been an overwhelming amount of legal demands for medicines, many of which involve medicines which have not yet been approved by ANVISA 8,9 and high-cost medicines, especially those present in the specialized component $4,5,6,10,11,12,13$.

Health technology assessment (HTA) and evidence-based medicine are tools that aim to increase the safe use of technologies, including medicines, through diverse and complementary analytical strategies 14,15. HTA assists decision-making by supporting the formulation of policies in the health sector and incorporation of technology. HTA usually employs summarizing methodologies (e.g. systematic reviews and meta-analyses) and economic assessments in healthcare (e.g. cost-effectiveness and costutility analyses) $16,17,18,19$, regarding a specific technology in subsidizing health decisions for a specific population. Evidence-based medicine, on the other hand, uses mostly the same analytical methods, but focuses on the individual. It integrates clinical practice and medical skills with the best assessment of external clinical evidence $18,19,20$ to improve the quality and effectiveness of interventions in healthcare provided to individual patients. Evidence-based medicine introduces the idea of using the best available evidence organized as a "hierarchy" of evidence, for which quality of the study and of the study design are the key 21 .

The decision to adopt a medicine for use in healthcare should be evidence-based ${ }^{22}$. Sound, cumulative evidence is employed to establish clinical and therapeutic guidelines, which, in turn, should subsidize clinical and managerial decision-making in the health system The use of legal pathways to obtain access to cutting-edge therapies does not imply that evidence may be disregarded; on the contrary, it may be said that because decision-making in legal disputes for medicines is very complex, the use of scientific evidence is an essential part of the process 23,24 .

The methods for collecting and summarizing evidence stem from HTA and from evidencebased medicine through different and complementary analytical strategies 14,17,18.

This work analyzed medicines demanded by plaintiffs in the judicial district of the city of Rio de Janeiro, Brazil, considering alternative therapies and scientific evidence, in order to establish categories for the decision-making process in SUS, regarding pharmaceutical services management, and in the Judiciary.

\section{Methodology}

We conducted a retrospective cross-sectional study. Data were collected from the following: primary lawsuit records from the Court of the State of Rio de Janeiro (source: http://www.tjrj. jus.br, accessed on 12/Sep/2008) database, and appeals records from two databases belonging to the State Health Secretariat (source: Secretaria de Estado de Saúde e Defesa Civil do Rio de Janeiro).

Criteria for inclusion of lawsuits were: individual legal actions filed from July 2007 to June 
2008 against the state of Rio de Janeiro at the Judicial District of the Capital (City of Rio de Janeiro) with supply of medicines as subject matter. A total of 1,263 lawsuits adhered to these criteria. Because an estimated $40 \%$ of lawsuits present specialized medicines, a sample was randomly selected to reflect this characteristic with $95 \%$ confidence. The final sample included 295 lawsuits. Fourteen lawsuits were excluded from the sample after examination of the records, because they had been misfiled regarding the subject matter.

The medicines represented in the resulting 281 actions were checked for approval within ANVISA, as well as for their presence in SUS funding components lists. Indications for medicines listed in the PCDT were additionally checked for compliance with the official protocol. This crosschecking eventually permitted the grouping of medicines with similar status.

Search for supporting evidence was conducted for unlisted medicines and for those prescribed in disagreement with government guideline (possible off label use). The Thomsom Micromedex - DRUGDEX System database (http://www.micromedexsolutions.com/micro medex2/librarian, accessed on 20/Jan/2011), was elected as the summarized evidence source because of its widespread availability in the public sector, favoring its access by personnel in health management and in the Judicial System. The scale for strength of evidence and of recommendation was applied to medicines and their respective indications.

The careful description of the requirements for medicines classification within these groups and the result of the search for supporting evidence were the origins of the analytical, mutually exclusive, categories.

The project was approved by the Ethics in Research Committee of the Sergio Arouca National School of Public Health, Oswaldo Cruz Foundation (CEP/ENSP/Fiocruz) under record number $33 / 09$.

\section{Results and discussion}

Three hundred and forty-four medicines were represented in the 281 demands. Most of them (229 or $66.6 \%$ ), were not included in any funding component list and 72 (20.9\%) belonged to the specialized component.

These results were not consistent with those published in previous studies that showed that most medicines under litigation were included in public funded lists 4,5,6,10,11,12. Recent studies have also shown similar results to the ones presented in this paper, which may indicate a change in the lawsuit profile $13,25,26$. This finding may be positive since a change of lawsuit profile may be related to better management of pharmaceutical services. A basic requirement for rational use is that listed essential medications are actually available in the system 27 . Nevertheless, other more down-to-earth explanations must be considered, such as pressure from the pharmaceutical industry on prescribers, regarding newer and costlier medicines, which results in non-adherence of healthcare professionals to the evidence-based funding components lists, a common enough situation in many settings $4,6,11$.

The original grouping of medicines and search for evidence resulted in six mutually exclusive categories of medicines.

The first category consisted of medicines which are included in public funding lists and that presented indications compliant with ANVISA and with national guidelines (PDCT). Examples in this category were peguilated interferon + ribavirin for chronic viral hepatitis $\mathrm{C}$ (VHC) and infliximab for rheumatoid arthritis.

As these are medicines that should at all times be available in the health system, demands may reflect failings in pharmaceutical services management. Because the judicial pathway and not an administrative one was followed, it is difficult to ascertain if the patient accessed pharmaceutical services in SUS at any given time and if so, what went wrong. The difficulty to gain access to information regarding the availability of certain medicines by patients and prescribers in SUS has been well established. They may be present in one health unit but not in others, confusing patients and care providers 28 . It is the system's responsibility to ensure that healthcare professionals and users may access medicines. This should be done by updating information on availability within the healthcare network.

The second category comprises specialized component medicines with indication supported by evidence and by ANVISA's market approval indication but in disagreement with PCDT therapeutic guidelines. Examples are simvastatin for the prevention of cardiovascular events in diabetic patients and the combination of formoterol and budesonide to treat chronic obstructive pulmonary disease. This category is related to a lack of updated guidelines, or lack of any guidelines, and to failings in the relationship between different bodies. One solution to these conflicts may reside in drawing up updated PCDT. The first PCDT were published in 2002 and updating of existent PCDT and the development of additional guidelines occurred mostly between 2009 and 2010, which demonstrates considerable lag time 
between the two. This interval is unacceptable, in face of the availability of newer, fresher evidence concerning the indications for dispensing specialized component medicines.

Policy implementation experiences in the health sector shows that policy adoption is not always homogeneous. Many constraints may arise from this and the population is sure to be affected 29 . Despite the fact that regulatory activities should be conducted apart from policy and provision in the health system, ANVISA is part of the Brazilian Ministry of Health and both should adhere to the same guidelines. If these government services cannot find agreement on issues regarding indication of publicly-funded medicines, it seems difficult to envision flawless transit of patients and prescribers through the system. Many country experiences show that government accountability at this level is not only possible but essential for dissemination of information to health system users and health care professionals. It is a tool to ensure patient rights as to the best possible available treatment.

In the PCDT for dyslipidemia, simvastatin is indicated for patients who have a high risk of developing cardiovascular events, with lipoprotein metabolism disorders and other dyslipidemiarelated diagnoses (CID E.78). There are three criteria for a patient's inclusion in a statin-based treatment: LDL cholesterol levels above 160mg/ $\mathrm{dL}$; acute myocardial infarction and LDL cholesterol levels above $100 \mathrm{mg} / \mathrm{dL}$; and patients whose LDL cholesterol levels are above $130 \mathrm{mg} / \mathrm{dL}$ and have at least one aggravating condition (coronary artery disease, previous myocardial infarction, atherosclerotic disease, diabetes, genetic syndromes such as familial hypercholesterolemia and familial combined hyperlipidemia or high absolute Framingham risk score: $\geq 9$ scores for men or $\geq 15$ scores for women) 30 .

Only three out of eighteen litigating patients were able meet these criteria 30 , but all eighteen received simvastatin as result of litigation, showing not only non-adherence to best evidence or to existing therapeutic guidelines by prescribers, but lack of compliance to best-evidence practices by the Judiciary.

Sometimes best evidence conflicted with PCDT. Regarding the evidence present in the existing guideline, litigating patients with diabetes would have to show LDL cholesterol levels above $130 \mathrm{mg} / \mathrm{dL}$ in order to receive simvastatin. However, other international evidence-supported guidelines 31 accept the use of simvastatin in the prevention of cardiovascular events in high-risk patients due to cardiovascular atherosclerotic disease or diabetes, irrespective of their cholesterol levels.
Off label indications for simvastatin, such as dementia, were present in lawsuits. However, newer evidence 32 , present in a systematic review of double-blind, randomized clinical trials with a total of 26,340 patients concluded that there is no sound evidence to support this off-label indication. Simvastatin was granted, anyway.

The pathological conditions of patients litigating for formoterol and budesonide were nonspecified chronic obstructive pulmonary disease, mixed asthma and non-specified asthma. The PCDT for asthma recommends the use of associations of medicines. However, although ANVISA has also approved this association for use in cases of chronic obstructive pulmonary disease based on sound scientific evidence, no PCDT for chronic obstructive pulmonary disease exists, which prevents dispensing.

The third category includes all medicines which are unavailable in the system and not yet incorporated by SUS, and for which no publicly financed therapeutic alternative exists. However, the use of these medicines is evidence-based and they have been approved by ANVISA. The examples are travoprost for glaucoma and ursodeoxycholic acid to treat primary biliary cirrhosis.

Pilocarpine and timolol are used as first-line treatment options for glaucoma and their use is supported by evidence but these medicines have not been funded over the years. It is important to highlight that the alternatives have been included in the National Essential Medicines List (RENAME) since 2006. Timolol is currently present in the essential medicines list for primary health care of the state of Rio de Janeiro.

Travoprost was requested by sufferers from primary open-angle glaucoma or from nonspecified glaucoma. Therefore, while no lack of evidence prevents the medicine from being dispensed, the use of travoprost should occur later in treatment, if patients do not respond well or are intolerant to other anti-glaucoma agents, such as pilocarpine and timolol 26. The lack of more consistent information about the patients in the lawsuits made it difficult to judge the actual need for travoprost use. In these cases, we may hypothesize that a delay in incorporating firstline anti-glaucoma agents into publicly-funded lists was an important determinant for the onset of legal demands.

There is no therapeutic alternative in publicly-funded lists for ursodeoxycholic acid, and many claims are related to the treatment of primary biliary cirrhosis, for which the use of this drug is supported by evidence and in spite of the fact that it is registered by ANVISA.

A fourth category is characterized by medicines with registered indications by ANVISA, sub- 
stantiated by evidence, but indicated mainly as second or third-line treatment options and for which alternatives are financed by the system. The following medicines were part of this category: infliximab for ankylosing spondylitis, clopidogrel for myocardial infarction and losartan for hypertension. Because they are not first-choice, analyzing patient history is an important step in the decision-making process. Balancing risks and benefits of use are also worth pondering within this category and further studies may be needed to consolidate available evidence for these medicines and respective indications. Once again it is up to the healthcare system management to take steps to increase adherence of prescribers to the publicly-funded lists and to encourage and stimulate prescription of medicines selected through an evidence-based process and standardized by PCDT 33

In this category there are first-line alternatives available in SUS. One of the alternative to clopidogrel is acetylsalicylic acid which is listed for the Primary Health Care Component. It is a lower-cost option that is effective and well tolerated by most patients 26. Clopidogrel is used as an option for patients who are intolerant or who have not responded properly to acetylsalicylic acid 26 . It is necessary to review the patient's history before furnishing it.

Losartan was included in the 2008 RENAME 34 and in Primary Health Care Component in 20102 but it remains as a second-choice treatment in cases of intolerance to widely-used angiotensinconverting enzyme inhibitors such as captopril and enalapril, which have been traditionally included in RENAME and in primary health care lists. Patients who requested losartan suffered from hypertension, hypertensive cardiac disease without heart failure and congestive heart failure. The use of losartan would only be justified if the patient did not tolerate the first-line choices.

The fifth category includes medicines for which long-term use in intended indications is not supported by evidence. Insulin analogs to treat types 1 and 2 diabetes were included in this category. The existence of evidence supporting short/mid-term use does not yet seem to justify the addition of such medicines to publiclyfunded lists. Existing evidence does not support adoption by health systems or clarify pathways for rational use.

Insulin is used to treat patients with type-1 and type- 2 diabetes when they do not respond to treatment with oral hypoglycemiants 34 . The Brazilian Ministry of Health currently provides only human NPH and regular insulin 2. Insulin analogs (lispro, aspart and glargine) come from recombinant DNA technology, whose structural modification leads to changes to its pharmacokinetic characteristics 34 .

A meta-analyses 35 with a total of 8,274 patients in randomized controlled trials showed that efficacy in glycemic control in long-term insulin analogs was identical to regular human insulin, and also found similar episodes of hypoglycemia. However, the study warns that there is no information on late complications such as diabetic retinopathy or nephropathy. The same result was found in the study by Davis 36 , whose claim is the clinical response of insulin analogs, and proves to be the same to the bolus administration of regular human insulin, when the injections are made in 10-15 and 30 minute periods prior to meals. According to Wannmacher 37, the advantages of insulin lispro and aspart are: (1) reduction of 20 to $30 \%$ of hypoglycemia, and (2) modest improvement $(0.3 \%$ to $0.5 \%)$ in glycosylated hemoglobin.

The RENAME 2008 didn't include insulin aspart, lispro and glargine and justified the exclusion by evidence from randomized clinical double-blind studies that have proven insufficient to ensure a therapeutic advantage of insulin lispro and insulin aspart compared to regular human insulin on treatment of diabetes mellitus type 134 . The Technical Committee and Multidisciplinary Update of the National List of Essential Medicines (COMARE) further argued that for patients with type 2 diabetes mellitus, there are no studies of insulin lispro compared to regular insulin, and there is insufficient evidence with the use of insulin aspart. In addition, the schedule of administration of insulin lispro or aspart immediately before meals was not enough to ensure that additional therapy provides some benefit to the recommended regimen of human insulin 34 . About insulin glargine, COMARE's report reveals that the reduction in glycosylated hemoglobin caused by this insulin is not followed by a lower incidence of severe hypoglycemia compared with other types of insulin. As such, the technical committee did not recommend the inclusion of any insulin analogs in RENAME 2008, or in subsequent national essential medicine lists or national publicly funded lists.

The duration of action of a particular type of insulin varies considerably from one patient to another and even within the same individual and this variability comes from different subcutaneous absorption rates, changes in diet and exercise (ANVISA. Bulário eletrônico 2009. http:// www.anvisa.gov.br/fila_bula/, accessed on 20/ Dec/2009) 37. Thus, for the dispensing of insulin analogs, it is necessary to examine the patient's history. 
The sixth category is a category of "rogue" medicines: those which do not yet have market approval in Brazil or those for which indications are explicitly unapproved by ANVISA. This was the case for sulthiame (prescribed for epilepsy), which was not approved by the regulatory agency. As for the latter, various examples were found: infliximab to treat psoriasis, olanzapine prescribed for global development disorders, clopidogrel for peripheral vascular disease, arterial embolism or thrombosis, and ursodeoxycholic acid to treat granulomatous hepatitis, hepatic fibrosis and neonatal jaundice caused by othrhepatocellular lesions (ANVISA. Bulário eletrônico 2009. http:// www.anvisa.gov.br/fila_bula/, accessed on 20/ Dec/2009). Demands do not seem to be justified, even if therapeutic alternatives are lacking for the above indications. No efficacy or safety may be established for these drugs in these indications and patients may be at risk.

The last two categories are the most sensitive with regard to safety of medicine use. For the second, third, fourth and sixth categories the question to ask is if in such cases there is a real need for the prescribed medicines. However there are some circumstances that justify its use: whether the plaintiff has an absolute contraindication to the use of the existing SUS alternative therapies; if, after use of a particular drug there has been no improvement in the clinical profile; or if there has been a true delay in incorporation in essential medicine lists.

The literature has shown that failure in incorporation has justified lawsuits in the past as has been the case regarding specific indications of adalimumab, etanercept, infliximab, levodopa + benserazide, peginterferon, rigvastamine, mesalazine, simvastatin, riluzole 6,9. However other cases are not supported by evidence which suggests that litigation represents pressure for SUS to adopt such medicines, targeting private interests more than health interests or therapeutic needs.

It may be necessary to analyze actual cases to support the relevance of claims when there is scientific evidence that justifies prescribing for the indication but the medicine is not included in official lists 10,33.

\section{Final considerations}

The analysis of legal demands and their support by scientific evidence allowed for the creation of categories of demanded medicines aiming to support decision-making and Pharmaceutical Services management. The categories are important to guide the drafting of new PCDT or to update existing ones. Furthermore they may help any process regarding inclusion of medicines in publicly funded lists or contribute to the necessary protection of patients receiving new and possibly unsafe medicines or subjected to irrational off-label use.

It is noteworthy to point out that the sources of data from legal actions often did not provide any information on other morbidities simultaneously experienced by the plaintiff, or the direct relationship between diagnoses and requests for medicines. This issue could impose limits to the analysis of actual cases when there is more than one prescribed medicine and/or more than one diagnosis. Nonetheless, HTA and evidence-based medicine tools helped to determine situations supported by evidence and those devoid of supporting evidence, clearly defined by objective information available in lawsuits.

The appropriate structuring of SUS pharmaceutical services ensures the supply of medicines selected by the system as a vital strategy for its maintenance and credibility. Identifying shortcomings in pharmaceutical services may provide information to healthcare managers on where to intervene in order to enforce the right to health. Pointing to the existence of alternative, safe and effective therapies within SUS while also alerting the system in respect to "rogue" medicines whose effectiveness and safety prevent recommendation of use regardless of indication are both correct actions that aim to guarantee the right to health. Another way of safeguarding the right to health is the careful in-depth analysis of particular cases, demanding more information about the reasons for prescribing so that a cautious decision might be made, preserving the patient and the system. 


\section{Resumen}

Las demandas han jugado un papel importante como una forma alternativa de acceso a los medicamentos en Brasil. Estas demandas incluyen los medicamentos utilizados en ensayos primarios, incluso los que continúan en investigación clínica y no están registrados en el país por la agencia de salud nacional (Agencia Nacional de Vigilancia Sanitaria - ANVISA). El objetivo fue analizar los fármacos presentes en las demandas de la región de Río de Janeiro durante el período de julio/2007 a junio/2008. Los fármacos presentes en 281 demandas fueron examinados por su indicación terapéutica, clasificados de acuerdo con su presencia en las listas de financiación pública, su aprobación por la ANVISA -lo que indica el cumplimiento de las directrices clínicas nacionales-, la existencia de terapias alternativas y la existencia de evidencias científicas. Se describieron seis categorías diferentes, en nuestra opinión, útiles para los gestores de la salud y la Justicia en el proceso de decisión. La búsqueda de evidencias científicas es importante para los medicamentos que no están incluidos en las listas, y también para los que no tienen alternativas terapéuticas.

Medicina Basada en Evidencia; Servicios Farmacéuticos; Derecho a la Salud; Evaluación de Tecnologías de Salud

\section{Contributors}

T. A. Figueiredo contributed to the design of the research work's central idea, data collection, database creation, data analysis, search for scientific evidence and writing of this paper. C. G. S. Osorio-de-Castro participated in the design of the research work's central idea and to writing this paper and proofreading its final version. V. L. E. Pepe collaborated on the design of the research work's central idea, data analysis and writing this paper.

\section{Acknowledgments}

We thank CNPq, who funded the project that originated this paper, called Judicialization and Public Health A Propoal for Analyzing and Monitoring of Individual Legal Claims for Access to Medications through bid notice MCT/CNPq/MS-SCTIE-DECIT/CT-Saúde n. 33/2007. Acknowledgments to Dr. Pedro Henrique Di Masi for authorizing the collection of data at the Warrants Division of the State Secretariat of Health and Emergency Management of Rio de Janeiro and to Dr. Ana Márcia Messeder for authorizing data collection at the State of Rio de Janeiro Pharmaceutical Services Superintendent's Office. We finally thank Dra. Kimberley Shoaf PhD for proof-reading the manuscript.

\section{Conflict of interest}

None declared.

\section{References}

1. Brasil. Lei no 8.080 de 19 de setembro de 1990. Dispõe sobre as condições para a promoção, proteção e recuperação da saúde, a organização e o funcionamento dos serviços correspondentes e dá outras providências. Diário Oficial da União 1990; 19 set.

2. Ministério da Saúde. Portaria GM/MS no 4.217 de 28 de dezembro de 2010. Aprova as normas de financiamento e execução do Componente Básico da Assistência Farmacêutica. Diário Oficial da União 2010; 29 dez.

3. Ministério da Saúde. Portaria GM/MS no 2.981/09 de 26 de novembro de 2009. Aprova o Componente Especializado da Assistência Farmacêutica. Diário Oficial da União 2009; 30 nov.

4. Romero LC. Judicialização das políticas de assistência farmacêutica: o caso do Distrito Federal. Brasília: Consultoria Legislativa do Senado Federal; 2008.
5. Vieira FS, Zucchi P. Distorções causadas pelas ações judiciais à política de medicamentos no Brasil. Rev Saúde Pública 2007; 41:214-22.

6. Messeder AM, Osorio-de-Castro CGS, Luiza VL Mandados judiciais como ferramenta para garantia do acesso a medicamentos no setor público: a experiência do Estado do Rio de Janeiro, Brasil. Cad Saúde Pública 2005; 21:525-34.

7. Sartório MJ. Política de medicamentos excepcionais no Espírito Santo: a questão da judicialização da demanda [Dissertação de Mestrado]. Porto Alegre: Programa de Pós-graduação em Ciências Farmacêuticas, Universidade Federal do Rio Grande do Sul; 2004.

8. Pepe VLE, Ventura M, Sant'Ana JMB, Figueiredo TA, Souza VR, Simas L, et al. Caracterização de demandas judiciais de fornecimento de medicamentos “essenciais" no Estado do Rio de Janeiro, Brasil. Cad Saúde Pública 2010; 26:461-71. 
9. Chieffi AL, Barata RB. Judicialização da política pública de assistência farmacêutica e eqüidade. Cad Saúde Pública 2009; 25:1839-49.

10. Pereira JR, Santos RI, Nascimento Junior JM, Schenkel EP. Análise das demandas judiciais para o fornecimento de medicamentos pela Secretaria de Estado da Saúde de Santa Catarina nos anos de 2003 e 2004. Ciênc Saúde Coletiva 2010; 15 Suppl 3:3551-60.

11. Sant'Ana JMB. Essencialidade e assistência farmacêutica: um estudo exploratório das demandas judiciais individuais para acesso a medicamentos no estado do Rio de Janeiro [Dissertação de Mestrado]. Rio de Janeiro: Escola Nacional de Saúde Pública Sergio Arouca, Fundação Oswaldo Cruz; 2009.

12. Pepe VL, Figueiredo TA, Simas L, Osorio-de-Castro CGS, Ventura M. A judicialização da saúde e os novos desafios da gestão da assistência farmacêutica. Ciênc Saúde Coletiva 2010; 15:2405-14.

13. Machado MAA, Acurcio FA, Brandão CMR, Faleiros DR, Guerra Jr. AA, Chearchiglia ML, et al. Judicialização do acesso a medicamentos no Estado de Minas Gerais, Brasil. Rev Saúde Pública 2011; 45:590-8.

14. Vianna CM, Caetano R. Avaliação tecnológica em saúde: introdução a alguns conceitos básicos. http://www.ims.uerj.br/downloads/cursoats/dow nload/Tecnologia_Saude_Alguns_conceitos.pdf (accessed on 10/Feb/2012).

15. Conselho Nacional de Secretários de Saúde. Assistência farmacêutica no SUS. Brasília: Conselho Nacional de Secretários de Saúde; 2007. (Coleção Progestores - Para Entender a Gestão do SUS, 7).

16. Krauss-Silva L. Avaliação tecnológica e análise custo-efetividade em saúde: a incorporação de tecnologias e a produção de diretrizes clínicas para o SUS. Ciênc Saúde Coletiva 2003; 8:501-20.

17. Almeida RT. Avaliação de tecnologia em saúde. In: Guimarães R, Angulo-Tuesta A, organizadores. Saúde no Brasil: contribuições para a agenda de prioridades de pesquisa. Brasília: Ministério da Saúde; 2004. p. 177-98.

18. Banta HD. The development of health technology assessment. Health Policy 2003; 63:121-32.

19. Drummond MF. Methods for the economic evaluation of healthcare programmes. Oxford: Oxford University Press; 1997.

20. Ottolenghi RH. Medicina basada en evidencias. Cartago: Libro Universitario Rigional; 2002.

21. Velasco-Garrido M, Busse R. Policy brief. Health technology assessment an introduction to objectives, role of evidence, and structure in Europe World Health Organization. Copenhagen: WHO European Centre for Health Policy; 2005.

22. Vianna CMM, Caetano R. Diretrizes metodológicas para estudos de avaliação econômica de tecnologias para o Ministério da Saúde. Brasília: Departamento de Ciência e Tecnologia, Secretaria de Ciência, Tecnologia e Insumos Estratégicos, Ministério da Saúde; 2007.

23. Malison M, Wilkins K, Otto B, Goodman RA, Churchill RE, White M, et al. Strengthening capacity in developing countries for evidence-based public health: the data for decision-making project. Soc Sci Med 2003; 57:1925-37.
24. Behague D, Tawiah C, Rosato M, Some T, Morrison J. Evidence-based policy-making: the implications of globally-applicable research for context-specific problem-solving in developing countries. Soc Sci Med 2009; 69:1539-46.

25. Ronsein JG. Análise do perfil das solicitações de medicamentos por demanda judicial no Estado de Santa Catarina no período de 2005 a 2008 [Dissertação de Mestrado]. Florianópolis: Universidade Federal de Santa Catarina; 2010.

26. Barcelos PC. Perfil de demandas judiciais de medicamentos da Secretaria de Estado da Saúde do Espírito Santo: um estudo exploratório [Dissertação de Mestrado]. Rio de Janeiro: Instituto de Medicina Social, Universidade do Estado do Rio de Janeiro; 2010.

27. Ministério da Saúde. Protocolos clínicos e diretrizes terapêuticas. Brasília: Ministério da Saúde; 2010. (Série A. Normas e Manuais Técnicos).

28. Marques SB. Judicialização da saúde e a proposta de regulamentação da integralidade de assistência farmacêutica no Brasil. In: Romero LC, Delduque MC, organizadores. Estudos de direito sanitário: a produção normativa e saúde. Brasília: Subsecretaria de Edições Técnicas, Senado Federal; 2011. p. 143-53.

29. Gershman S, Santos MAB. O Sistema Único de Saúde como desdobramento das políticas de saúde do Século XX. Rev Bras Ciênc Soc 2006; 21: 177-227.

30. Ministério da Saúde. Protocolos clínicos e diretrizes terapêuticas. Brasília: Ministperio da Saúde; 2002.

31. World Health Organization. WHO model formulary 2008. Geneva: World Health Organization; 2008.

32. McGuinness B, Bullock R, Craig D, Kerr E, Passmore P. Statins for the treatment of Alzheimer's disease and dementia (protocol). Cochrane Database Syst Rev 2009; (1):CD007514.

33. Macedo EI. A importância da análise técnica para a tomada de decisão do fornecimento de medicamentos pela via judicial [Dissertação de Mestrado]. Sorocaba: Universidade de Sorocaba; 2010.

34. Departamento de Assistência Farmacêutica e Insumos Estratégicos, Secretaria de Ciência, Tecnologia e Insumos Estratégicos, Ministério da Saúde. Relação Nacional de Medicamentos Essenciais RENAME 2008. Brasília: Ministério da Saúde; 2008. (Série B. Textos Básicos de Saúde).

35. Siebenhofe A, Plank J, Berghold A, Jeitler K, Horvath K, Narath M, et al. Short acting insulin analogues versus regular human insulin in patients with diabetes mellitus. Cochrane Database Syst Rev 2004; (2):CD003287.

36. Davis SN. Insulin, oral hypoglycemic agents, and the pharmacology of endocrine pancreas. In: Bruton LL, Lazo JS, Parker KL, editors. Goodman \& Gilman's the pharmacological basis of therapeutics. 11th Ed. New York: McGraw-Hill; 2006. p. 161345.

37. Wannmacher L. Novas insulinas: qual a real vantagem? Uso Racional de Medicamentos: Temas Selecionados 2005; 2:1-6.

Submitted on $07 /$ Nov/2012

Final version resubmitted on $03 / \mathrm{Jun} / 2013$

Approved on 04/Jul/2013 